\title{
PELAPISAN SOSIAL-BUDAYA PESISIR KELURAHAN MANGKANG KULON, SEMARANG
}

\author{
Kartika Dewi \\ Peneliti Independen Sosial-Budaya Pesisir \\ kakartikadewi@gmail.com
}

\begin{abstract}
The purpose of this study is to identify economic conditions of the fishers and fish farmers and to understand the social stratification and work relation among the coastal society in Mangkang Kulon, a coastal area, with the main income almost entirely dependent on the sea and coast land. Social stratification is a society's categorization of people into socioeconomic strata, based upon their occupation and income, wealth and social status, or derived power (social and political). As such, social stratification is the relative position of person or group within a sociocultural system, category, geographic region, or social unit. Social stratification is the distinction of population or society into classes in multilevel classes (hierarchical); its manifestation is the presence of the upper class, middle class, and lower class.Primary data were collected from the local fishers. Four fishers and two brackish water pond cultivators were in-depth interviewed. Secondary data (village monograph) were collected from the village office. Data were analyzed descriptively. There were three social stratifications found out and formed in the area of Rukun Warga I Mangkang Kulon based on the income among coastal society. First the upper strata, which consists of gogol tambak, second the middle strata which consists of tambak pandega, third the lower strata of individual petty fishers and tambak manual workers.
\end{abstract}

Key words: sociocultural stratification, coastal culture, fishers, brackish water pond cultivators.

\section{Pendahuluan}

Pelapisan sosial-budaya (sociocultural stratification) adalah penggolongan manusia ke dalam kelompok-kelompok berdasarkan kelas dan status yang memiliki kriteria tertentu di dalam kelompok masyarakat. Untuk terbentuknya pelapisan maka diperlukan pertemuan dua orang individu atau lebih sehingga terjadi perbedaan sosial dalam masyarakat. Stratifikasi terbentuk ketika individu dikelompok-kelompokkan ke dalam strata tertentu yang pada setiap anggota dalam strata tersebut memiliki kesamaan karakteristik.

Masyarakat pesisir adalah masyarakat yang mendiami wilayah sekitaran pesisir dan biasanya menggantungkan hidupnya pada laut sebagai sumber mencari penghasilan. Tidak terkecuali masyarakat pesisir Kelurahan Mangkang Kulon, Kota Semarang, mereka juga membentuk pelapisan sosial-budaya yang mengelompokkan masyarakat dengan kriteria tertentu. Dalam suatu masyarakat hal yang lazim untuk melihat adanya pelapisan sosial-budaya adalah berdasarkan kelas ekonomi yang bisa dilihat dari mata pencaharian atau pekerjaan penduduk. Dalam masyarakat pesisir terdapat kelompok-kelompok masyarakat nelayan, petani tambak, hingga pekerja industri dengan masing-masing tingkatan stratifikasi sosial-budayanya.

Kelompok masyarakat nelayan terbagi-bagi ke dalam strata sosial-budaya. Penggolongan sosial dalam masyarakat nelayan menurut Kusnadi (2002), pada dasarnya dapat ditinjau dari tiga sudut pandang. Pertama, dari segi penguasaan alat produksi atau peralatan tangkap (perahu, jaring dan perlengkapan yang lain), struktur masyarakat nelayan terbagi dalam kategori nelayan pemilik (alat-alat produksi) dan nelayan buruh. Kedua, ditinjau dari tingkat skala investasi modal usahanya, struktur masyarakat nelayan terbagi ke dalam kategori nelayan besar dan nelayan kecil. Nelayan, disebut sebagai nelayan besar 
karena jumlah modal yang diinvestasikan dalam usaha perikanan relatif banyak, sedangkan pada nelayan kecil justru sebaliknya. Ketiga, dipandang dari tingkat teknologi peralatan tangkap yang digunakan, masyarakat nelayan terbagi ke dalam kategori nelayan modern dan nelayan tradisional.

Mirip dengan strata sosial-budaya yang ada pada masyarakat nelayan, masyarakat petani tambak juga terdiri dari 3 strata sosial yang dominan, seperti berikut: (1) Strata atas adalah mereka yang menguasai tambak yang luas, (2) Strata menengah yang memiliki luas tambak sedang dan kecil, dan (3) Strata paling bawah adalah para pengelola dan buruh.

Pelapisan tersebut dipengaruhi oleh berbagai hal yang perlu diteliti lebih lanjut agar mengetahui bentuk-bentuk setiap pelapisan sosial-budaya dan karakteristik anggota dalam setiap pelapisan yang terjadi pada masyarakat pesisir di Kelurahan Mangkang Kulon, Kota Semarang. Pertanyaan-pertanyaan yang diajukan meliputi sebagai berikut, 1) apakah terdapat pelapisan sosial-budaya (sociocultural stratification) pada masyarakat pesisir Kelurahan Mangkang Kulon? 2) bagaimanakah ciri-ciri pelapisan sosialbudaya yang terbentuk pada masyarakat pesisir Kelurahan Mangkang Kulon? 3) Apakah persamaan-persamaan yang terbentuk dalam pelapisan sosial-budaya masyarakat pesisir Mangkang Kulon? Apakah perbedaan-perbedaan yang terbentuk dalam pelapisan sosial-budaya masyarakat pesisir Kelurahan Mangkang Kulon?

\section{Kelurahan Mangkang Kulon dan Mata Pencaharian}

Mangkang Kulon merupakan Kelurahan paling barat di wilayah Kecamatan Tugu, Kota Semarang, Provinsi Jawa Tengah. Kecamatan Tugu memiliki luas wilayah seluas $31.78 \mathrm{~km}^{2}$, yang berbatasan di sebelah utara dengan Laut Jawa, timur dengan Kecamatan Semarang Barat, selatan dengan Kecamatan Ngaliyan, dan barat dengan Kabupaten Kendal. Kecamatan Tugu berada di dataran rendah 14 meter di atas permukaan laut dan Kelurahan Mangkang Kulon merupakan daerah yang berada di wilayah pesisir di sebelah utara, sehingga masyarakat sekitar sangat bergantung kepada laut sebagai mata pencaharian dan sumber penghasilan. Jumlah nelayan tangkap rajungan di RW 1 Kelurahan Mangkang Kulon berkisar 160 orang dengan 8 kelompok nelayan dan jumlah petani tambak udang dan bandeng berkisar 33 orang, dengan 2 kelompok petambak.

\section{Stratifikasi Sosial}

Stratifikasi sosial (social stratification) adalah pembedaan masyarakat dalam strata atau lapisan sosial-ekonomi, berdasarkan pekerjaan dan penghasilannya, kepemilikan atau kekayaan dan status sosialnya atau kekuasaan sosial dan politiknya. Dengan demikian stratifikasi membeda-bedakan dan membagi masyarakat ke dalam kelas-kelas secara hierarkis, bertingkat-tingkat, dengan perwujudan adanya kelas tinggi dan kelaskelas yang lebih rendah. Menurut Max Weber (1946), "the term 'class' refers to any group of people that is found in the same class situation" (Weber, 1946: 181), istilah kelas merujuk pada sekelompok orang yang ditemukan dalam situasi kelas yang sama. Stratifikasi sosial secara mendasar membedakan dan membagi masyarakat ke dalam 3 (tiga) kelas, yakni (1) kelas atas (the upper class), (2) kelas menengah (the middle class), dan (3) kelas bawah (the lower class) (Saunders, 1990).

Penghasilan dari pekerjaan pada setiap anggota dalam kelompok masyarakat akan membentuk kelas-kelas jika terdapat perbedaan penghasilan antar anggota. Kelaskelas yang terbentuk akan membagi anggota masyarakat berdasar kepada harta benda dan gaya hidup. Pembagian ini akan mengelompokkan masyarakat dengan status kaya, berkecukupan dan miskin. Setiap anggota yang telah dikelompokkan dalam stratifikasi yang sama akan memiliki 
kesamaan gaya hidup, kesamaan jumlah penghasilan, dan kemiripan harta benda.

Sistem berlapis-lapis dalam suatu masyarakat dapat bersifat tertutup (closed social stratification) dan ada yang bersifat terbuka (open social stratification). Sistem tertutup yaitu setiap anggota tidak mempunyai kesempatan untuk nik strata maupun turun strata. Sistem yang terbuka terjadi sebaliknya, yaitu setiap anggota masyarakat mempunyai kesempatan untuk berusaha dengan kecakapan sendiri untuk naik lapisan, atau bagi yang tidak beruntung, untuk jatuh dari lapisan yang atas ke lapisan di bawahnya (Soekanto, 1987).

Pada stratifikasi sosial yang membagi masyarakat ke dalam kelas-kelas berdasarkan sudut pandang ekonomi maka stratifikasi semacam ini bisa dikatakan stratifikasi sosial sistem terbuka. Setiap anggota masyarakat yang berada pada kelas ekonomi rendah bisa naik ke kelas ekonomi yang lebih tinggi jika berhasil meningkatkan kualitas hidupnya. Begitu juga sebaliknya, setiap anggota mayarakat yang berada pada kelas ekonomi tinggi bisa turun ke kelas ekonomi rendah jika tidak bisa mempertahankan status ekonominya. Stratifikasi sosial yang bersifat tertutup terjadi kepada stratifikasi sosial yang berdasar kepada status, atau stratifikasi yang terjadi pada masyarakat praindustri yang membagi manusia ke dalam perbudakan, estate, dan kasta.

\section{1. Stratifikasi Sosial-budaya pada Masyarakat Nelayan}

Undang-undang nomor 45 tahun 2009 tentang perubahan Undang-undang nomor 31 tahun 2004 tentang perikanan mendefinisikan nelayan adalah orang yang mata pencahariaannya melakukan penangkapan ikan. Penggolongan sosial dalam masyarakat nelayan, menurut Kusnadi (2002), pada dasarnya dapat ditinjau dari tiga sudut pandang. Pertama, dari segi penguasaan alat produksi atau peralatan tangkap (perahu, jaring dan perlengkapan yang lain), struktur masyarakat nelayan terbagi dalam kategori nelayan pemilik (alat-alat produksi) dan nelayan buruh. Nelayan buruh tidak memiliki alat-alat produksi dan dalam kegiatan sebuah unit perahu, nelayan buruh hanya menyumbangkan jasa tenaganya dengan memperoleh hak-hak yang sangat terbatas. Kedua, ditinjau dari tingkat skala investasi modal usahanya, struktur masyarakat nelayan terbagi ke dalam kategori nelayan besar dan nelayan kecil. Nelayan, disebut sebagai nelayan besar karena jumlah modal yang diinvestasikan dalam usaha perikanan relatif banyak, sedangkan pada nelayan kecil justru sebaliknya. Ketiga, dipandang dari tingkat teknologi peralatan tangkap yang digunakan, masyarakat nelayan terbagi ke dalam kategori nelayan modern dan nelayan tradisional. Nelayan-nelayan modern menggunakan teknologi penangkapan yang lebih canggih dibandingkan dengan nelayan tradisional.

Masyarakat nelayan menurut Wahyuningsih, et al (1997), dapat dibagi tiga jika dilihat dari sudut pemilikan modal, yaitu sebagai berikut.

1). Nelayan juragan. Nelayan ini merupakan nelayan pemilik perahu dan alat penangkap ikan yang mampu mengubah para nelayan pekerja sabagai pembantu dalam usahanya menangkap ikan di laut. Nelayan ini mempunyai tanah yang digarap pada waktu musim paceklik. Nelayan juragan ada tiga macam yaitu nelayan juragan laut, nelayan juragan darat yang mengendalikan usahanya dari daratan, dan orang yang memiliki perahu, alat penangkap ikan dan uang tetapi bukan nelayan asli, yang disebut tauke (toke) atau cakong.

2). Nelayan pekerja, yaitu nelayan yang tidak memiliki alat produksi dan modal, tetapi memiliki tenaga yang dijual kepada nelayan juragan untuk membantu menjalankan usaha penangkapan ikan di laut. Nelayan ini disebut juga nelayan penggarap atau sawi (awak perahu nelayan). Hubungan kerja antara nelayan ini berlaku perjanjian tidak tertulis yang sudah dilakukan sejak ratusan tahun yang lalu. Juragan dalam hal ini berkewajiban 
menyediakan bahan makanan dan bahan bakar untuk keperluan operasi penangkapan ikan, dan bahan makanan untuk dapur keluarga yang ditinggalkan selama berlayar. Hasil tangkapan di laut dibagi menurut peraturan tertentu yang berbeda-beda antara juragan yang satu dengan juragan lainnya, setelah dikurangi semua biaya operasi.

3). Nelayan pemilik merupakan nelayan yang kurang mampu. Nelayan ini hanya mempunyai perahu kecil untuk keperluan dirinya sendiri dan alat penangkap ikan sederhana, karena itu disebut juga nelayan perorangan atau nelayan miskin. Nelayan ini tidak memiliki tanah untuk digarap pada waktu musim paceklik (angin barat). Nelayan ini sebagian besar tidak mempunyai modal kerja sendiri, tetapi meminjam dari pelepas uang dengan perjanjian tertentu. Nelayan yang umumnya memulai usahanya dari bawah, semakin lama meningkat menjadi nelayan juragan.

Berdasarkan wawancara yang mendalam dengan 4 orang nelayan di RW 1 Kelurahan Mangkang Kulon, didapatkan ciri-ciri nelayan daerah tersebut, sebagai berikut.

(a) Berusia produktif (20-45 tahun).

(b) Berpendidikan dasar hingga menengah pertama (tamatan SD hingga tamatan SMP).

(c) Kepemilikan alat tangkap dan kapal adalah milik sendiri yaitu, alat tangkap berupa jaring dan bubu, sedangkan kapal, yaitu kapal motor tempel.

(d) Kepemilikan rumah sendiri, yang dapat dikatakan layak huni tapi sangat kecil untuk dihuni sekeluarga.

(e) Pendapatan nelayan dengan sistem pendapatan per hari yaitu antara Rp 50.000-100.000/hari (pendapatan bersih).

(f) Mengutamakan pendidikan anak karena tidak ingin anak-anaknya memperoleh penghidupan yang sama seperti ayah mereka.

(g) Istri hanya seorang ibu rumah tangga yang kadang membantu hasil tangkapan. (h) Tidak memiliki usaha sampingan.

(i) Aktif mengikuti unit kelompok/organisasi nelayan.

Berdasarkan ciri-ciri tersebut di atas, maka nelayan RW 1 Kelurahan Mangkang Kulon dapat dikelompokkan sebagai nelayan kecil. Undang-undang nomor 45 tahun 2009 mendefinisikan nelayan kecil sebagai orang yang mata pencahariaannya melakukan penangkapan ikan untuk memenuhi kebutuhan hidup sehari-hari yang menggunakan kapal perikanan berukuran paling besar $5 \mathrm{gt} /$ gross ton. Nelayan kecil dapat dikatakan juga sebagai nelayan pemilik. Nelayan pemilik merupakan nelayan yang kurang mampu, yang hanya mempunyai perahu kecil untuk keperluan dirinya sendiri dan alat penangkap ikan sederhana, karena itu disebut juga nelayan perorangan atau nelayan miskin. Nelayan ini tidak memiliki tanah untuk digarap pada waktu musim paceklik, seperti yang disampaikan oleh Wahyuningsih, et. al. (1997). Nelayan kecil dapat dikatakan pula sebagai nelayan tradisional karena terbatas pada alat tangkap dan kapal yang sangat sederhana dan belum menggunakan teknologi yang canggih.

Unsur-unsur yang mengikat suatu kelompok sosial bisa disebut sebagai pelapisan sosial, menurut Murniatmo (2000) disebabkan oleh adanya hal-hal sebagai berikut.

(a) Kesamaan ciri-ciri dalam kelompok sosial.

(b) Kedudukan yang sama bagi anggota kelompok sosial.

(c) Terjadinya hubungan yang intim di antara individu-individu sebagai anggota kelompok.

Dengan demikian dengan banyaknya kesamaan ciri-ciri pada nelayan RW 1 kelurahan Mangkang Kulon maka terbentuklah kelompok sosial yaitu kelompok nelayan kecil. Setiap anggota kelompok nelayan kecil ini memiliki kedudukan yang sama, tidak ada yang terkelompokkan menjadi kelas tinggi atau kelas paling rendah karena mereka memiliki kesamaan penghasilan, bentuk rumah, alat 
mencari ikan, dan gaya hidup. Pada kelompok nelayan kecil yang terbentuk di RW 1 Kelurahan Mangkang Kulon terdapat rasa memiliki dan solidaritas yang sangat tinggi satu sama lain, mereka aktif mengikuti unit kegiatan nelayan dan menghormati hak-hak setiap anggota nelayan.

Oleh karena nelayan di RW 1 Mangkang Kulon termasuk ke dalam satu kelompok, yaitu kelompok nelayan kecil sehingga tidak terjadi pelapisan atau strata antar nelayan di daerah ini, tapi yang menarik saat penulis di desa ini adalah terlihatnya perbedaan atau pelapisan masyarakat di kiri jalan dan di kanan jalan. Pada deretan perkampungan di sebelah kanan jalan dihuni oleh rumah-rumah petak kecil yang hanya memiliki 1 (satu) kamar dan serupa semua, sedangkan pada kiri jalan terdapat rumah-rumah yang boleh dikatakan mewah, berukuran besar, memiliki AC, dan memiliki 2 (dua) kamar, atau lebih. Rumah ini juga lengkap dengan kendaraan pribadi seperti sepeda motor matik dan mobil. Hal ini jelas menunjukkan adanya pelapisan sosial pada RW 1 Kelurahan Mangkang Kulon ini. Ternyata setelah penulis teliti dengan melakukan observasi dan wawancara pada nelayan mengenai para penghuni deretan ruas kiri jalan, mereka adalah para pemilik usaha tambak bandeng dan udang, bukan nelayan atau bahkan nelayan kecil.

Dalam artikel ini masyarakat nelayan disebut dengan penggolongan stratifikasi sosial-budaya, karena kelompok nelayan bukan hanya merupakan kelompok sosial dalam sistem sosial, melainkan mereka menjalankan kebiasaan-kebiasaan, tradisitradisi, penghasilan, bentuk rumah, alat mencari ikan, dan gaya hidup, yang relatif sama, sehingga mereka dapat disebut sebagai kelompok sosial-budaya, sebagai anggota-anggota dari sistem sosial-budaya yang khas yaitu sistem sosial-budaya nelayan.

\section{2. Stratifikasi Sosial-budaya pada Masyarakat Petani Tambak}

Demikian pula, dalam artikel ini masyarakat petani tambak disebut dengan penggolongan stratifikasi sosial-budaya, karena para petani tambak bukan hanya merupakan kelompok sosial dalam sistem sosial, melainkan mereka menjalankan kebiasaan-kebiasaan, cara-cara, tradisitradisi, penghasilan, bentuk rumah, peralatan budi daya ikan, dan gaya hidup, yang kurang lebih sama, sehingga mereka dapat disebut sebagai kelompok sosial-budaya, sebagai anggota-anggota dari sistem sosial-budaya yang khas yaitu sistem sosial-budaya petani tambak atau petambak.

Alternatif usaha perikanan rakyat selain penangkapan adalah usaha-usaha budi daya ikan dan udang dalam tambak (brackish water pond) yang memanfaatkan kawasan pesisir sebagai lahan bagi usaha perikanan budi daya, baik budidaya perikanan berbasis lahan di darat (landbased aquaculture) maupun di laut (marine based aquaculture). Jenis budi daya lahan di darat diwakili oleh pertambakan yang sangat umum dipakai sebagai tempat membesarkan ikan bandeng (chanos chanos) dan udang (penaeus monodon).

Tambak merupakan kolam yang dibangun di area pasang surut dan digunakan untuk memelihara bandeng, udang dan hewan air lainnya yang bisa hidup di air payau. Petani tambak adalah orang yang melaksanakan kegiatan budidaya tambak.

Pola stratifikasi yang lebih luas pada petani petambak seperti penelitian yang dilakukan oleh Purnamasari, dkk (2002), bahwa pada masyarakat petambak Desa Babulu Laut ditemui beberapa kelompok ponggawa dan petambak. Kelompok ponggawa memiliki dua tipe yaitu: 1) ponggawa yang memiliki dan menyakapkan lahan tambak, dan 2) ponggawa yang tidak memiliki lahan tambak. Kelompok petambak terdiri 3 (tiga) tipe yaitu (1) petambak pemilik terikat yang menyakapkan lahan tambaknya, (2) petambak pemilik terikat yang mengelola lahan tambaknya sendiri, (3) petambak penyakap yang menggarap lahan tambak milik ponggawa. 
Petani tambak dibedakan berdasarkan kepemilikan tanah, lahan tambak, menjadi tiga kelompok (Fatmawati, 2007) sebagai berikut.

(1). Gogol Tambak (Pemilik Tambak)

Gogol tambak merupakan kelompok penghuni desa tambak yang paling kaya dan paling cerdik. Sebagian besar memang berasal dari keluarga kaya. Rumahnya selalu terbuat dari tembok sedang tambak yang mereka miliki luasnya dapat berpuluh-puluh hektar. Sebagian dari warisan orang tua dan sebagian lagi dari pembelian baru. Umumnya mereka memiliki modal usaha sendiri untuk mengusahakan tambak walau tidak terlalu besar. Keluarga-keluarga kelompok ini memiliki pendidikan yang lebih tinggi dari kelompok lain.

2). Wong angguran (petani penggarap, petani penyewa, pemaron, atau pandega).

Wong angguran merupakan kelompok petani tambak yang tidak memiliki tambak sendiri tetapi hanya tenaga saja dan rumah tinggal, meskipun rumah sederhana. Mereka orang yang selalu menggarap, mengerjakan tambak orang lain, baik dengan menyewa, dengan perjanjian bagi hasil separuhseparuh (sehingga disebut juga pemaron), maupun hanya menjual tenaga sebagai buruh tetap.

3). Wong Manukan

Wong Manukan merupakan kelompok orang yang tidak mempunyai apa-apa kecuali tenaga sebagai buruh kasar. Keadaannya sangat memprihatinkan, hanya tinggal di sebuah gubuk yang didirikan di dekat tambak. Kelompok ini bisa dikatakan kelompok miskin. Mereka tidak mempunyai keahlian apa-apa dan selalu dipakai tenaganya untuk buruh kasar pada waktu dibutuhkan untuk penggalian tanah, pembangunan pematang, pengangkutan hasil tambak, panen hasil tambak, dan lain-lain.

Dengan demikian, petani tambak terdiri dari 3 strata sosial yang dominan yaitu sebagai berikut.

(1) Strata atas adalah mereka yang menguasai tanah tambak yang luas;

(2) Strata menengah yang memiliki luas tanah tambak sedang/kecil; dan
(3) Strata paling bawah adalah para pengelola/buruh tambak.

Pada RW 1 Kelurahan Mangkang Kulon terdapat pengelompokan petani tambak dengan ciri-ciri sebagai berikut.

(1) Strata atas, dengan ciri-ciri sebagai berikut.

(a) Tambak milik sendiri, baik dari warisan orang tua, maupun bertambah dengan pembelian baru, dengan luas hampir mencapai 3 ha.

(b) Pemilik tambak merupakan orang yang berpendidikan tinggi (tamatan $\mathrm{S} 1)$.

(c) Modal tambak sendiri dan membentuk perusahaan.

(d) Memiliki rumah gedung dan kendaraan pribadi yang tergolong mewah seperti mobil.

(2) Strata menengah, dengan ciri-ciri sebagai berikut.

(a) Tambak dikelola sendiri, tetapi lahan tambak didapat dengan menyewa, sistemnya dengan membayar lahan tambak pertahun sebesar $\mathrm{Rp}$ 2,5juta/tahun per petak.

(b) Pemilik tambak merupakan orang yang sedang membangun usaha tambak dari bawah dan biasanya merupakan mantan nelayan yang ingin mengubah nasib menjadi petambak.

(c) Berpendidikan dasar hingga menengah pertama (tamatan SD-SMP).

(d). Luas tambak hanya berkisar 3-6 petak (sekitar 1-2 ha).

(e). Rumah tembok, kepunyaan sendiri, walau tidak sebagus rumah petambak strata atas.

(3). Strata bawah, dengan ciri-ciri sebagai berikut.

(a) Pengelola/buruh atau pekerja kasar harian yang datang dari luar daerah untuk membantu sebagai pekerja di tambak.

(b). Bekerja pada pemilik tambak strata atas.

(c). Berpendidikan dasar (tamatan SD).

(d). Tidak mempunyai keahlian.

(e). Rumah gubuk yang dibangun di sekitar tambak. 
Petambak di RW 1 Mangkang Kulon mendiami ruas sebelah kiri jalan, dan membangun rumah mereka dekat dengan lahan tambak. Kehidupan mereka secara materi lebih baik bila dibandingkan dengan nelayan yang mendiami ruas kanan jalan. Berbeda dengan nelayan yang hanya membentuk satu kelompok yaitu nelayan kecil/nelayan tradisional, pada petani tambak terbentuk kelompok atau strata yaitu (1) strata atas, yang terdiri dari para pemilik tambak/pengusaha tambak, (2) strata menengah yaitu penyewa tambak, dan terakhir (3) strata bawah, yaitu buruh tambak. Strata sosial ini terbentuk karena adanya perbedaan secara kepemilikan materi atau lahan di antara petani tambak.

\section{Simpulan: Stratifikasi Sosial-budaya Pesisir}

Wilayah pesisir memiliki karakteristik yang khas, merupakan wilayah pencampuran atau pertemuan antara laut dan darat. Pada kawasan pesisir pemanfaatan lahan telah dilakukan untuk berbagai keperluan seperti pertambakan, pertanian, pemukiman, industri dan pariwisata dan pemanfaatan lainnya. Masyarakat yang mendiami wilayah ini, selanjutnya disebut masyarakat pesisir, yang menggantungkan hidupnya pada laut sebagai sumber ekonomi. Stratifikasi sosial-budaya masyarakat pesisir yang terbentuk di RW 1 Kelurahan Mangkang Kulon, secara garis besar dapat digambarkan sebagai berikut.

(1). Strata atas yaitu kelompok masyarakat yang memilki penghasilan ekonomi paling tinggi, memiliki rumah tembok, kendaraan pribadi berupa mobil, memiliki usaha pribadi berupa lahan tambak, memiliki pendidikan tinggi yaitu lulusan S1. Kelompok ini diisi oleh petambak kelas gogol tambak.

(2). Strata menengah yaitu kelompok masyarakat yang memiliki penghasilan lebih rendah dibandingkan strata atas, memiliki rumah sederhana dan layak huni, memiliki kendaraan sepeda motor, mengelola usaha sendiri di lahan sewa dengan sistem bayar sewa per tahun. Kelompok ini diisi oleh petambak penyewa, yaitu petambak yang menyewa lahan tambak untuk dikelola sendiri dan hasilnya dinikmati sendiri.

(3). Strata bawah yaitu kelompok masyarakat yang ekonominya tergolong rendah, pendapatannya hanya cukup untuk memenuhi kebutuhan sehari-hari; memiliki rumah yang kecil dan bisa dikatakan tidak layak huni. Kelompok ini diisi oleh nelayan tradisional atau nelayan kecil, dan buruh kasar tambak.

Pelapisan sosial-budaya (sociocultural stratification) dalam masyarakat RW 1 Kelurahan Mangkang Kulon adalah, kelompok petani tambak pemilik, kelompok penyewa lahan tambak, kelompok pandega tambak, buruh tambak dan kelompok nelayan kecil.

Karakteristik sociocultural stratification yang terbentuk di masyarakat pesisir Mangkang Kulon adalah sebagai berikut.

(1). Strata atas yaitu kelompok masyarakat yang memilki penghasilan paling tinggi, memiliki rumah tembok, kendaraan pribadi berupa mobil, memiliki lahan usaha pribadi, memiliki pendidikan tinggi yaitu S1. Kelompok ini diisi oleh petambak kelas gogol tambak.

(2). Strata menengah yaitu kelompok masyarakat yang memiliki penghasilan lebih rendah dibandingkan strata atas, memiliki rumah sederhana dan layak huni, memiliki kendaraan sepeda motor, mengelola usaha sendiri di lahan tambak sewaan tahunan. Kelompok ini diisi oleh petambak penyewa, yaitu petambak yang menyewa lahan tambak untuk dikelola sendiri dan hasilnya dinikmati sendiri.

(3). Strata bawah yaitu kelompok masyarakat yang penghasilannya rendah, hanya cukup untuk memenuhi kebutuhan sehari-hari; mereka memiliki rumah yang kecil dan bisa dikatakan tidak layak huni. Kelompok ini diisi oleh nelayan tradisional atau nelayan kecil, dan buruh kasar tambak.

Penelitian tentang sistem sosialbudaya masyarakat pesisir kiranya perlu dilanjutkan dengan lebih mendalam dan meluas untuk memahami masyarakat pesisir 
dengan stratifikasi sosial-budaya pesisir, yang berjumlah anggota besar dan berkarakteristik khas.

\section{Daftar Pustaka}

Amaluddin, Moh. 1987. Kemiskinan dan Polarisasi Sosial. Jakarta: Universitas Indonesia.

Fatmawati, Siti Dewi. 2007. Karakteristik Demografi dan Sosial Ekonomi Petani Tambak Desa Surodadi, Kecamatan Sayung Kabupaten Demak.[Skripsi]. Fakultas Ilmu Sosial, Universitas Negeri Semarang.

Kusnadi. 2002. Nelayan - Strategi Adaptasi dan Jaringan Sosial. Bandung: Humaniora Utama Press.

Macionis, J. J. 2000. Society: The Basics. Upper Saddle River, New Jersey: Prentice Hall

Murniatmo. 2000. Khazanah Budaya Lokal. Yogyakarta: Adicita Press.

Purnamasari, Elly; Titik Sumantri, Lala M. Kolopaking, 2002. Pola Hubungan Produksi Ponggawa-Tambak: Suatu Bentuk Ikatan Patron-Klien (Studi
Kasus Masyarakat Petambak Di Desa Babulu Laut Kecamatan Babulu Kabupaten Pasir Kalimantan Timur. Jurnal Forum Pascasarjana, Vol. 25.No. 2. April

Ritzer, George. 2004. Teori Sosiologi. Edisi Terbaru. Yogyakarta: Kreasi Wacana.

Saunders, Peter. 1990. Social Class and Stratification. London: Routledge.

Soekanto, S. 1987. Sosiologi. Suatu Pengantar. Ed.3. Jakarta: Rajawali Pers.

Wahyuningsih, et al. 1997. Budaya Kerja Nelayan Indonesia di Daerah Jawa Tengah. Yogyakarta: Kreasi Wacana.

Weber, Max. 1946. From Max Weber. Translated, Edited, and with Introduction by $\mathrm{H}$. H. Gerth and C. Wright Mills. New York: Oxford University Press. 
LAMPIRAN

1. Informan

1. 1. Nelayan

1) Nama: M. Ramadhan

Umur: 33 tahun

Alat tangkap: kepunyaan sendiri berupa sebuah motor tempel,dan jaring

Pendidikan terakhir: SMP

Jumlah anak/istri: 3 anak/ 1 istri

Rumah : milik sendiri, kecil berukuran 1 kamar

Pendapatan: Rp 50.000-100.000/hari

Pendidikan anak: masih kelas $1 \mathrm{SD}$, sisanyabelum sekolah

Pekerjaan istri: Ibu Rumah Tangga

Organisasi yang diikuti : unit kelompok nelayan

2) Nama: Rudi Utomo

Umur: 21

Alat tangkap: kepunyaan sendiri berupa sebuah motor tempel, dan jaring

Pendidikan terakhir: SMP

Jumlah anak/istri: 1 anak/ 1 istri

Rumah : milik sendiri, kecil berukuran 1 kamar

Pendapatan: Rp 50.000-100.000/hari

Pendidikan anak: belum usia sekolah

Pekerjaan istri: Karyawan Pabrik

Organisasi yang diikuti: unit kelompok nelayan

3) Nama: Sarianto

Umur: 39 tahun

Alat tangkap: kepunyaan sendiri berupa sebuah motor tempel, dan jaring rajungan dan bubu

Pendidikan terakhir: SMP

Jumlah anak/istri: 3 anak/ 1 istri

Rumah : milik sendiri, kecil berukuran 1 kamar

Pendapatan: Rp 50.000-100.000/hari

Pendidikan anak: SMA kelas 2, SD kelas 2, sisanya belum sekolah

Pekerjaan istri: Ibu Rumah Tangga

Organisasi yang diikuti : unit kelompok nelayan

Organisasi yang diikuti : unit kelompok nelayan

4) Nama: Sunarto

Umur: 40 tahun

Alat tangkap: kepunyaan sendiri berupa sebuah motor tempel,dan jaring rajungan

Pendidikan terakhir: SD

Jumlah anak/istri: 2 anak/ 1 istri

Rumah : milik sendiri, kecil berukuran 1 kamar

Pendapatan: Rp 50.000-100.000/hari

Pendidikan anak: SMP kelas 2, sisanya belum sekolah

Pekerjaan istri: Ibu Rumah Tangga.

1. 2. Petani Tambak

1) Nama: Achmadi

Umur: 45 tahun

Luas tambak: 6 petak, 200m²/petak

Kepemilikan tanah tambak: sewa 
Pendidikan terakhir: SD

Jumlah anak/istri: 2 anak/ 1 istri

Rumah : milik sendiri, sederhana

Pendapatan: Rp 5-7 juta/bulan

Pendidikan anak: SMA

Pekerjaan istri: Petambak

2) Nama: Soni

Umur: 33 tahun

Luas tambak: 10 ha

Kepemilikan tanah tambak: milik sendiri

Pendidikan terakhir: Strata 1

Jumlah anak/istri: 2 anak/ 1 istri

Rumah : milik sendiri, mewah

Pendapatan: Rp 50-100juta/bulan

Pendidikan anak: masih SD

Pekerjaan istri: IRT

\section{Gambar-gambar}

Gambar 1. Motor Tempel Nelayan

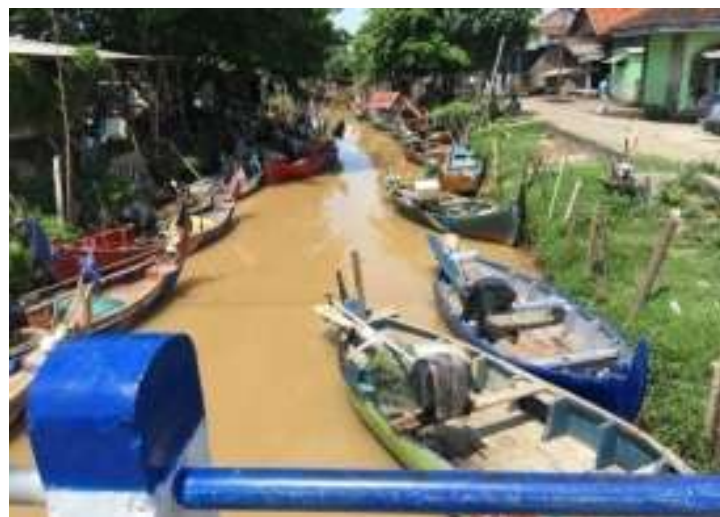

Gambar 3. Rumah Gogol Tambak

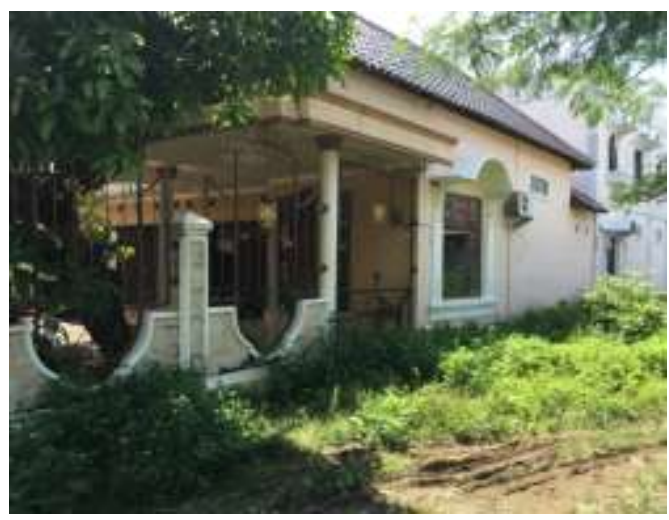

Gambar 2. Rumah Nelayan

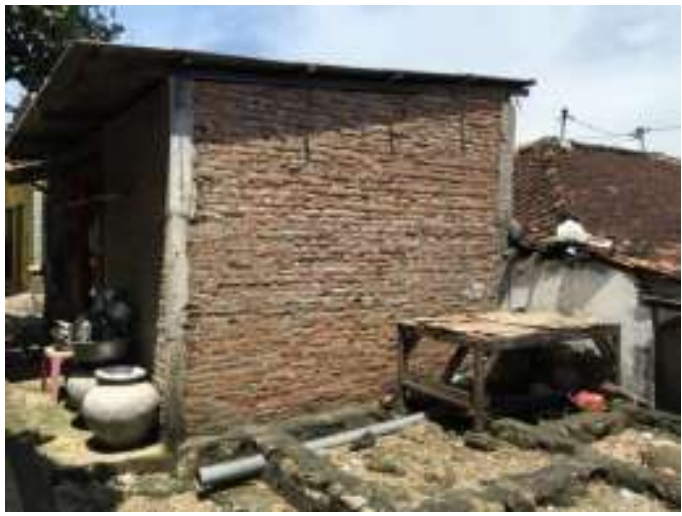

Gambar 4. Rumah Petambak Pandega

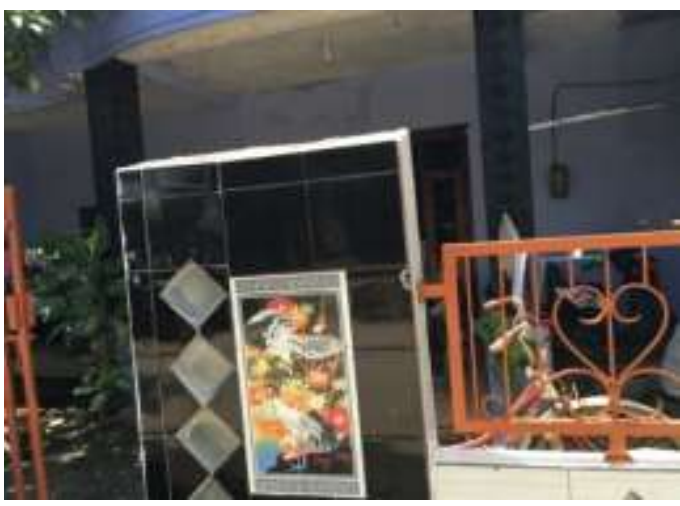

